\title{
The teaching model reform of curriculum design practices for materials molding and control engineering in the machine direction
}

\author{
Huayang Zhao, Li Li, Fang Qian, Chun Ying, Yuntao Wang \\ Inner Mongolia University for the Nationalities, School of mechanical engineering, Inner Mongolia \\ Tongliao 028043, China
}

Keywords: Material forming and control engineering; Energy efficiency score table; Virtual practice; Simulation training.

\begin{abstract}
Combined with practical teaching status quo in the current mechanical undergraduate majors, the paper analyzes the material forming and control engineering major practice teaching mode and the main problems, then it gives ideas and implementation of practical teaching reform. The paper creatively gives energy efficiency evaluation form in teaching link and introduces virtual internships systems and the use of case teaching, then students participate in actual production needs and the research direction of teachers in order to complete graduation design. The trinity of completing the whole undergraduate teaching process is important for improving practical ability and creative ability of students.
\end{abstract}

\section{Introduction}

Innovative ability and practical ability are required in the new century, the university technological innovation has been included in the national innovation system. Both the theoretical basis of professional knowledge and practical ability in solving specific engineering project problems are needed for those engineering students. Therefore the practice teaching for the students in Moscow specialty in the entire university culture process is very important .The professional training mode of covering the field of thermal processing, mechanical engineering and automation profession, based on the original machinery professional, is currently one of the three main training modes of material forming profession[1]. Advanced manufacturing technology will become the dominant technology development direction in the future, material forming and control engineering profession is a mechanical disciplines which possesses of typical material disciplines characteristics, and the basic knowledge of the mechanical and materials disciplines constitutes the basic knowledge system of this discipline. This feature determines that the talents culture of material forming and control engineering professional must be wide caliber, and the basics of material forming and control engineering professional which is structured by mechanical and materials disciplines together are bound to be strong. With the integration of the old professional and the development of technology, the professional training will inevitably move towards deep foundation, wide caliber models [2]. In terms of training specifications, those schools put more emphasis on knowledge structure, and the ability structure and quality structure are lack of detailed requirements, and they are the same lack of positioning level in the training specifications. The set of practice teaching does not correspond to training target, and thus the training target cannot be achieved. Broadening the profession caliber is the general trend of reform, being unique is the key of professional, and the "degree" of the professional caliber width settings is the combination of the two points. The main target is to lay the foundation of development for the students, so that they can have a new and greater development after graduation. Therefore, the undergraduate teaching should fade the occupational tendency, emphasis on the culture of students' scientific thought, scientific method and scientific spirit, enable students not only to learn how to learn, learn to work, but also to learn to explore and create. 


\section{Current practice teaching mode and existing problem in the colleges}

For those colleges, the current practice teaching mainly includes three aspects, the first is the experiment synchronized with the curriculum and the independent experimental curriculum, and the second is curriculum design and graduation design, the third is internship on campus and off-campus. There currently are some major problems among these three aspects.

Curriculum experiments are mostly demonstration or verification experiments based on the curriculum content, the students don't realize the status and effect of the experiment in the engineering project, and they are with a certain degree of blindness and passivity during the experiment, the effect of ability culture and quality training for the students is relatively weak, leading to the majority of students are not active in the experiments, not compliance with the code of experiments, don't operated in strict accordance with practices specification.

For curriculum design or graduation project, the main problem is that the design title is single, thus giving many students the opportunity to copy drawings and calculation data, and it is meaningless exercise. The graduation design's drawbacks that many teachers don't have fixed research fields or projects, most graduate students choose a design title by themselves, lead to the lack of innovation, weakly relative to new technologies, having no research value or has already been solved in the choosing of the subject topics. Another important phenomenon is that many students don't take graduate design and buy or download some papers online, and make some casually rewrite to pass the detection of school and graduate.

For school metalworking practice, electronic practice, graduation manufacture and many other training process, the main problem is that metalworking practice don't achieve the purpose of unity of design, technology and manufacturing processes. In metalworking practice, the performance and other conditions should be given by the teacher, then students can design technology program, set process specification according to the materials and equipment provided by practice environments, and take detection, analysis, write practice report by themselves [3]. The main problem of graduation manufacture practice is that the fund from school for this practice is not enough which leads to the short practice time, simple practice process and form, and because the enterprises currently do not give any chance for the students to operate in hands, this type of practice is just like a visit practice, the students find many kinds of reasons not to participate in the practice, so the effect of this practice is quite optimistic [4].

\section{The reform idea of practice teaching}

Undergraduate education in colleges should be oriented by the effect of student learning, combined with knowledge transferring, capacity culture and value shaping trinity. In the process of practice teaching, a manner gradually from simple to difficult is taken, the training content and standards of the basic skills, professional ability, comprehensive ability, innovation ability is clear, the comprehensive analysis's training content and standards at all levels are scientific and effective, the multimedia virtual practice is applied to practice teaching, practice content is closely linked to social needs to build a viable material forming and control engineering practice teaching system, and to exercise students' teamwork ability.

\section{The reform program of practice teaching}

Curriculum design is closely linked to culture goal, practice teaching is combined with theory teaching, and the exercise for students take the form of actual operation and independent design. Recommended program of student's quality requirement and occupational ability culture. Practice teaching has now been widely emphasized by all schools, but the concept of the subordination of its dependent theory teaching of teachers and students have not been changed, the establishment of assessment criteria and system that teaching practice characteristic, teaching practice level and students' practical abilities can be reflected is an effective method to solve this problem. 
Every detail on practice teaching is assessed through indicators, practice teaching energy efficiency score table is established, and the entire practice teaching process can be checked by the table to improve students' scientific literacy. Meanwhile teachers can complete the teaching process based on this table.

Table 1 practice teaching energy efficiency score table of material forming and control engineering profession

\begin{tabular}{|c|c|c|c|c|c|c|c|}
\hline \multirow[b]{3}{*}{$\begin{array}{c}\text { Weight } \\
\text { coefficient } \\
10\end{array}$} & \multirow[b]{3}{*}{ Key points } & \multicolumn{6}{|c|}{ Experiment hours of metallurgy and heat treatment } \\
\hline & & \multicolumn{6}{|c|}{ Experiment kinds/10 hours } \\
\hline & & $\begin{array}{l}\text { Material } \\
\text { hardness } \\
\text { testing }\end{array}$ & $\begin{array}{c}\text { Use of } \\
\text { microscope } \\
\text { and } \\
\text { preparation } \\
\text { of sample }\end{array}$ & $\begin{array}{c}\text { Observation } \\
\text { and analysis } \\
\text { of iron-carbon } \\
\text { equilibrium } \\
\text { organization }\end{array}$ & $\begin{array}{c}\text { Heat } \\
\text { treatment } \\
\text { of steel }\end{array}$ & $\begin{array}{l}\text { Organization } \\
\text { and analysis } \\
\text { of cast } \\
\text { colored tissue }\end{array}$ & total \\
\hline & & 2 & 2 & 2 & 2 & 2 & time \\
\hline & & 0.2 & 0.2 & 0.2 & 0.2 & 0.2 & percent \\
\hline 1.5 & $\begin{array}{c}\text { Video } \\
\text { learning }\end{array}$ & 2.5 & 3 & 3 & 2.5 & 2 & 13 \\
\hline 1.5 & $\begin{array}{l}\text { Research } \\
\text { preparation }\end{array}$ & 2 & 2.5 & 3 & 2.5 & 2.5 & 12.5 \\
\hline 2 & $\begin{array}{l}\text { Handle } \\
\text { process }\end{array}$ & 3 & 3 & 3 & 3 & 3 & 15 \\
\hline 2 & $\begin{array}{c}\text { Data } \\
\text { treatment }\end{array}$ & 2 & 2.5 & 3 & 3 & 3 & 13.5 \\
\hline 1 & $\begin{array}{l}\text { Experiment } \\
\text { result }\end{array}$ & 1.5 & 1 & 2 & 2 & 2 & 8.5 \\
\hline & teamwork & & & & & & \\
\hline 2 & $\begin{array}{l}\text { Experiment } \\
\text { report }\end{array}$ & 3 & 2.5 & 3 & 3 & 3 & 14.5 \\
\hline \multicolumn{2}{|c|}{ total } & 14 & 14.5 & 17 & 16 & 15.5 & 77 \\
\hline
\end{tabular}

The table is designed according to the percentage system, assessment points in the table can be adjusted according to the specific circumstances or changed in experimental practice. Metallurgy and heat treatment is set as an example to illustrate the use method.

We can break down each experiment or practice, and do weight analysis. Assume the total points is 10 , and a course of specific types of experiments or practice teaching is 10 points, allocated according to the proportion hours then the final out is 100 points. Teaching process is analyzed and carded according to the teaching energy efficiency and transferred to corresponding statistics to give each student the final score. For example, the necessary points are weighted for metal material and heat treatment experiments, and the corresponding score is given, and the experiment grade can be obtained directly through excel function, and experimental ability of students can be evaluated comprehensively. Professional competence certification and practice capabilities are combined to set up assessment system. The detailed requirements for students' skill training and certification have already given in 11 version teaching plan.

For those simulation course, such as three dimensions solid modeling, material forming CAE, and CNC machining, case teaching can be used to make students understand theory in practice process and feel friendly with professional knowledge. 
One of the objectives of practice teaching is to enhance the understanding and application of students to the theory, and improve the overall quality of students. A widespread phenomenon in the college is that students don't pay attention to experiment, especially a groups of several people and the whole class practice. In order to make the students to pay attention to experiment and practice, experiments practice process must be carefully designed, and program should be developed reasonably to enable students achieve quality requirements. Multimedia virtual practice is combined with manufacture practice and set up assessment criteria

For the problems existed in practice in the past, in order to complete the practice in high quality and ensure the practical effect in the limited time, not only the openness of campus practice base should be ensured, but also a stable off-campus practice base and high-quality instructor team is required, and the form of practice should be various. To make up for the drawbacks of the current practice, the introduction of multimedia virtual practice is a good idea. material forming and control engineering professional teachers team in this respect in Shenyang University has done a lot of work and obtain good effects. The reform and achievement of manufacture practice can be learned. On this basis, professional orientation and the actual situation are taken into consideration and further digestion and absorption are taken to establish our own assessment methods.

Manufacture actual requirement and teacher's research orientation are combined to determine graduation design title. The leading technology orientation of material forming and control engineering profession is advanced manufacturing technology, which requires the professional to absorb the latest achievements in machinery, electronics, information, materials, modern management and so on. The graduation design title of students should be as broad as possible, so that students can be exercised in terms of material forming and manufacture processing, mold manufacturing method and theory, design simulation, automatic control, tolerance design, processing methods. More contact and communication with the enterprise, and broadened research scope, such as practicing in Dongfeng Motor enterprise and Changchun FAW and some other local enterprise can make them apply the knowledge learned to solve practical problems encountered in the production, and combine practice and theory well. At the same time, opening degree of laboratory should be increased, research and innovation project should be set up for students, and science and technology competition should be organized to create research opportunities for students to participate in innovative activities as soon as possible and lay good foundation for graduation design.

\section{Conclusion}

As we all know, the "innovation society" is initiated all over the country, and innovation is not fantasy, it should be the new idea and concept proposed based on some theory or practice. The combination of theory and practice, the improvement of students' practical ability in colleges and the improvement of the quality of education should be payed much attention. For the orientation, curriculum and the main problems of material forming and control engineering professional in our school, the ideas and methods of reform of practice teaching mode is proposed. The reform program of experiment, practice and curriculum and graduation design is proposed based on three aspects: assessment to experiment process based on energy efficiency table, virtual practice system based on advanced manufacturing technology and processing methods, graduation design from teacher's research, student's research and enterprise. These programs will be implemented in the advanced technology exercise of mold manufacturing and material forming with the CNC machining technology, special processing technology, and computer simulation technology as the core and in the modern engineering practice with the crafts design of model manufacture as the main line. 


\section{Acknowledgements}

This paper is supported by National machinery/foundation course teaching steering committee of Engineering training teaching steering committee/Education scientific research project project (JJ-GX-jy201422) and the scientific research fund project of Inner Mongolia University for the Nationalities (MDYB2013044).

\section{Reference}

[1]Jia lili, Kong fanxin, Ke xugui. Exploration and practice of teaching reform of material forming and control engineering profession[J]. Journal of Nanjing Institute of Technology:social science edition, 2007, 7(4):50-55.

[2]Yu haizhou Liu wenjun, Zhao guangwei. Research on characteristic and main curriculum system of material forming and control engineering profession[J]. China Electric Power Education, 2012, (12):34-35.

[3]Li sheng. Consideration about practice teaching of material forming and control engineering profession[J]. Journal of Chongqing University of Science and Technology:social science edition, 2006, (4):137-139.

[4]Yu baoyi, Li runxia, Xiang qingchun. Simulation practice system of material forming and control engineering profession[J]. China Electric Power Education , 2012, (34):100-101.

[5]Fan jun, Wang leigang. Exploration on dynamic practice teaching of material forming and control engineering profession[J]. China Science and Technology Innovation Herald, 2012, (14):203-204. 